\title{
Implementation Overview of Minangkabau Society's life Philosophy on the Custom House Interior Plan
}

\author{
Dina Fatimah \\ Interior Design Department \\ Universitas Komputer Indonesia \\ Bandung, Indonesia \\ dina.fatimah@email.unikom.ac.id
}

\begin{abstract}
The purpose of this research was to explore Minangkabau culture as one of the great cultures in the archipelago. The main basis of Minangkabau's social system is custom and religion. This is seen in the Minangkabau society's life philosophy "Adat Basandi Syara', Syara' basandi Istanbul" (custom built upon sharia; sharia built upon AlQur'an). Before Islam came to the land of the Minangkabau, its community system is based on "Adat basandi Mufakat, mufakat basandi Alua Patuik" (discussion). Rumah Gadang that functions as a residential facility is one of the Minangkabau culture buildings, which is an embodiment of values, customs, and desires of the community (folk tradition). The purpose of this research is to determine the depth extent of the "Adat Basandi Syara ', syara'basandi kitabullah" application in Rumah Gadang's interior design. The qualitative descriptive is used as research method. The review concludes that the religious rule inclusion in traditional order verified the existence of social formation in Minangkabau society culture. The interior design of Rumah Gadang shows the existence of the unity between the customs and the religion. The findings conclude that the inclusion of religious rules in adat order, proves the social formation in the culture of the Minangkabau society.
\end{abstract}

Keywords - Culture, Minangkabau, Rumah Gadang, Adat, Religion.

\section{INTRODUCTION}

The review in this study is an activity to interpret an interior (interior room) that originates from traditional architectural works, namely the Minangkabau's Rumah Gadang. As an area that is quite influential in Malay culture, Minangkabau architecture is one of the topics of discussion for architectural designers. Previous research states that the design of traditional Minangkabau architecture is one form of ideal, social and material forms of a culture. Rumah Gadang is one of the traditional architectures that are owned by Minangkabau culture. In its journey and development, traditional Minangkabau architecture is influenced by elements of geography, geology, climate, religion, customs, philosophy or outlook on life and historical events and background [1]. Minangkabau traditional architecture has in common with the architecture of the ethnic groups that inhabit the Indonesian archipelago which is located in the tropical region along the equator. The rules and habits of ancestors have been successfully imaged in the appearance of their architectural works [2]. Rumah Gadang is said to be large (gadang) not because of its great physicality but its function, among other things as a family residence, as a symbol of the presence of a people and as a center of life and harmony [3]. The Minangkabau gadang house is a cultural result of a tribe that runs along the west coast of central Sumatra. As ethnic groups that adhere to the philosophy of "nature developed into a teacher", they harmonize their lives in a harmonious but also dynamic nature structure then express it in their traditional house architecture [4].

The stages in making traditional architecture in this case the Rumah Gadang has rules that have been established by their ancestors. These rules are the result of adaptation for a people in Minangkabau society. That is, the rules they make through a process first and are the result of mature thinking in their decisions.

Much research has been done on Minangkabau architecture, including about Minangkabau vernacular architecture on the study of architecture and the existence of Rumah Gadang seen from the influence and changes in cultural values. Topology, morphology and typology studies at the Minangkabau Gadang House by Agus, E which concluded that Minangkabau architecture is an expression and reflection of the social culture of the people [5]. The Rumah Gadang was created to have a strong and distinctive foundation, both its structure, shape, layout, and also the use of its ornaments in Gadang house to add the elements [6]. Space pattern in house building in natural area Surambi Pagu river - West Sumatera by Abdullah, M. Result of this study give a description of spatial patterns inside Rumah Gadang from some type of pattern in that location. Study of topology, morphology and typology in gadang minangkabau house by Agus, E and matrilineal Culture of 
the Minangkabau Society in the architecture of the Rumah Gadang by Yovita and Chalid [7,8]. The studies mentioned above basically mention the philosophy of the Minangkabau people which is implemented in the architecture of Rumah Gadang, but does not mention the results of the slice between custom and religion, so that the aim of the research is to find out the depth of the application of the "adat basandi syara ", syara' basandi kitabullah "in the design interior of Rumah Gadang. The qualitative descriptive is used as research method.

\section{METHOD}

The method used in this research is qualitative descriptive. First, the description of the Rumah Gadang is carried out. Secondly, a discussion was focused on the presentation of the interior space of the Rumah Gadang which was associated with the philosophy of life of the Minangkabau people. At this stage interpretation of the interior space is carried out.

\section{RESULTS AND DISCUSSION}

The entry of Islam in Minangkabau originated from the arrival of the Arabs to the area of Pariaman (Minangkabau region) and created the village. Since the spread of Islam throughout Minangkabau, then the influence of Hinduism began to disappear. The leaders of the community are deliberating and producing agreements that the Islamicbased adat is to be adhered to as a result of the rapid development of Islam at that time. Then it is known until now "Adat Basandi Syara ', Syara' Basandi Kitabullah" (Shari'a Customary Shari'a, Shari'a Cutomary Kitab Allah).

Minangkabau history is divided into 3 parts:

- Primordial period Indigenous Indonesians have confidence in the layers of the world. In this case the belief in occult power and spirits is respected in all the actions of the people, even though the public realizes that this is contrary to religion.

- The period of Hindu influence and the Minangkabau Kingdom in the early days of the Minangkabau HinduBuddhist religion, the doctrine of nature was influenced by the thought of the natural elements symbolized by the gods. Nature with all its elements is seen in all four. Minangkabau people look to "nature" by mentioning the water-wind-fire-and land is the unity of the natural elements that cannot be separated. That element lives in harmony. The element is gathered dynamically in a system of cause and effect. At this time, it was strongly influenced by the leadership of Raja Adityawarman who came from Majapahit (Pamalayu expedition). He concentrated his administration in Pagaruyung.

- Islam-Minang Period The interpretation of the shape of the building during the Islamic period is associated with the beauty of the structure of the human body created by God as the highest being. The building is analogous to the human body, with the parts of the head, body and feet of the building. This division has also been found in the Hindu era, this is shown by the division of the temple anatomy which consists of the head, body and legs.

Minangkabau culture is centered on religion, customs and culture that forms rules in the lives of its people. In the 1918 Encyclopaedie Van Nederlandsch Oost-Indie it is mentioned that in the 14th century there was a kingdom called Minangkabau whose area of power includes Central Sumatra between the kingdom of Manjunto and Singkel River (west), Palembang kingdom and Siak River (east). Figure 1, explains the lineage of the Minangkabau King. In the 17th century the Dutch entered and the kingdom of Minangkabau lived only the original area of Padang Darat. According to the hereditary narrative, the Minangkabau king came from Iskandar Zulkarnain (Alexander de Groote) who had three sons of each Alif Emperor in Turkey (Rum or Ruhum), Emperor Depang became king in China and the Royal Emperor became king in Minangkabau. Alexander de Groote came for the first time to the Pariangan (near the present-day Padang Panjang) and founded the first kingdom in the history of Minangkabau, the kingdom of Koto Batu. The son of Alexander de groote, the Sultan of Sri Maharaja Diraja marries some Minang daughters [9]. The pedigree can be described as follows:

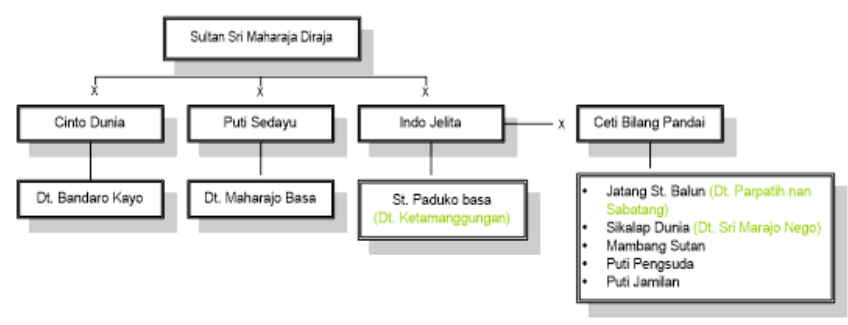

Fig 1: The Lineage of the Minangkabau King. (Source: Fatimah, D. 2006)

Dt. Ketamunggangan and Dt. Perpatih Nan Sabatang established the kingdom of Dusun Tuo after the system of the kingdom of Koto Batu in Pariangan was abolished. Throughout this period, they formulated the adat rules of Minangkabau, namely:

- The four customary ("adat yang sebenar adat, adat yang diadatkan, adat yang teradat, adat istiadat")

- The four words (the heirloom, the word was first met, the word was then searched, the word agreed)

- Four villages (“taratak, dusun, koto, nagari”)

- Four laws ("undang Luhak, undang Nagari, undang dalam nagari, undang duapuluh")

- Fourth law ("hukum lama, hukum "manggamo", hukum bersama, hukum "bakarano"). After Islam entered into the "hukum baina, hukum karano, hukum ilmu, and hukum ijtihad".

- "Cupak yang dua" (cupak usali, cupak buatan)

These master rules which ultimately form the tribes and the rulers of the rulers. Distribution of Luhak also occur at this time which produces Luhak nan Tigo (Luhak Tanah Datar, Luhak Agam, and Luhak Limapuluh Kota). This Luhak will form the nagari (custom territory) in Minangkabau. 
The main basis of the Minangkabau community system is custom and religion. This is seen in the meaning of the phrase "Adat Basandi Syara, Syara Basandi Kitabullah". While before Islam goes to Minangkabau society its social system is based on "Adat Basandi Mufakat, Mufakat Basandi Alua Patuik".

The existence of harmony between the customs and the religion because Minangkabau is based on the clues that exist in nature that is " Alam Takambang Jadi Guru ". In social systems, liberalism is one of the fundamental principles in the Minangkabau philosophy because nature always teaches people to give and give is a noble act. If learned deeply, Minangkabau custom is a concept of life that Minangkabau ancestors have prepared for his descendants whose purpose is to achieve a happy life of the world and the hereafter.

The basic nature of Minang people is mutual ownership. That is, each individual becomes a shared property of his group. On the contrary, each group belongs to all individuals who belong to that group. The mutual sense of belonging is the source of the sense of solidarity, togetherness, and helpfulness. The entry of religious rules in adat order, proves the social formation in the culture of Minangkabau society. This social formation becomes a concrete reference in the Minangkabau society to restructure the social order.

Amos Rapoport views architecture as a reflection of a cultural system, namely the design of buildings that includes changes that are most useful to the physical environment. He can be considered as a construction that deliberately changes the physical environment according to the rules that apply in the community concerned [10]. In the book "A History of Architecture on the Comparative Method", said that architectural research is intended to find differences in the disclosure of architecture in each region. The purpose of the above is to clearly show the nature (character) of the architectural buildings of each region, compare a style (style) with others and pay attention to specific geographical, geological, climate, religious, social and historical influences that support the formation of a style.

Figure 2 is one example of Rumah Gdang type. Rumah Gadang has characteristics in its sloping out construction and curved construction forms that are often found in vertical or horizontal lines

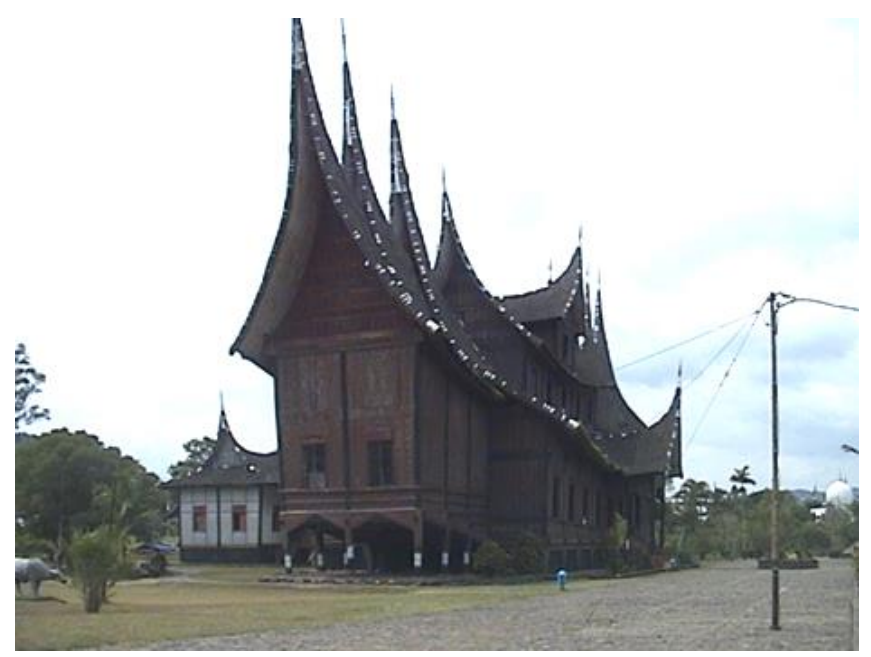

Fig 2. Pagaruyung Palace (one example of the Rumah Gadang type) Source: (Fatimah,D. 2006)

When viewed from its basic form, the Rumah Gadang is an asymmetrical rectangle that expands upwards. The transverse is sharply curved and also sloping with a lower center. The arch on the roof is sharp like a buffalo horn line, while the arch of the building is sloping like a ship's body. The line of enlarged rectangles upwards is combined with a low curved line in the middle, this relates to the teachings of their lives.

Rumah Gadang or a large house is a residential building, has a lot of rooms but the numbers are odd, a spacious living room with a typical building shape. In addition to living quarters, Rumah Gadang is also used as a place to perform various activities and traditional ceremonies such as marriage ceremonies, death and establishing / establishing a headman. Rumah Gadang is also often called a traditional house. For Minangkabau people the Rumah Gadang has a multifunction. Not only a place to hold traditional ceremonies, but also a "center of information" of a tribe / tribe for the existence of its members. From the gadang house they know, know, and control every action and behavior. Rumah Gadang has a diverse name according to shape, size and style of solitude (Bodi Caniago and Koto Piliang) and Luhak style. According to his form, he is commonly called a gonjong house or a Rumah Bagonjong, because the shape of the jagged roof rises.

Minangkabau traditional houses do not have a definite size. A Rumah Gadang is based on the calculation of the amount of space, in odd numbers, starting from three. The number of rooms is usually seven but there are also the number of rooms is seventeen. At the left and right ends there is a platform consisting of at least two levels and as many as three levels. The platform is a staircase (terraced) located in the middle of the width of the house. The room on the bridge is usually used on special occasions, and is usually used in weddings. To climb the Rumah Gadang must go through the stairs that are located in front of the house, and at the top of this stairs are given a roof that rises forward. In the Rumah Gadang, the room is not separated by dividing barriers, but with different floor heights, except for the bedroom (cubicle). The kitchen is built separately on the 
back of the house attached to the wall. Sometimes the stairs are made of smaller sizes from the front. In addition to cooking, it is also used as a place to eat mothers with girls. Whereas the underside becomes a place to store agricultural equipment or also where women meet. But there are also some who use some under the house for firewood and chicken coops as well as storage of garden products such as coconut, sweet potatoes, and so on. Under this house around it is closed with ranjung or sasak lattice or trellis. In addition to the functions previously stated, the function of the Rumah Gadang is related to certain conditions, for example, every married woman has a room. The youngest woman gets a final room which in turn will move midway if she also has a husband. Old women and children get rooms near the kitchen. Teenage girls get shared rooms at the other end. Whereas old men, widowers and bachelors slept in surau (mosques / mushala) belonging to their respective people. As a place of consensus, Rumah Gadang is the central building of all members of the community in discussing their problems together. As a place to conduct ceremonies, Rumah Gadang is an important place for various purposes such as the place of coronation of the prince, an important banquet center and other necessities such as the place where the headman awaits respected guests.

The construction of Rumah Gadang is accompanied by a series of activities in a sequence that must be done. The order aims to facilitate the process of implementing a house establishment in order to achieve the desired goal. Rumah Gadang is divided into sections which each have a special function. The whole part is a loose room except the bedroom. The inside is divided into a hall and a space marked by a pole. The pole went from face to back and left to right. Poles that stretch from face to back indicate the length, while the pole from left to right indicates space. The amount depends on the size of the house, can be two, three, and four. The room consists of odd numbers between three and eleven.

Function of home parts based on a "lanjar" or line: - Back "lanjar": Usually used for rooms. The number of rooms depends on the number of women living in them. Small rooms are used for sleeping and changing clothes. Room for girl at the end of the room. The left end is used for newlyweds or the youngest married couples. The position of the room is placed there so that they can avoid the frenzied bustle of the house.

- Second "lanjar": As a special place for room occupants. For example, where they eat and wait for their guests. It is as wide as the width of a room that is right in front of their rooms.

- Third "lanjar": It is the center of the house with a fourstorey house and is the edge of the house with three rows. Serves to wait for guests occupying their respective rooms in the room and where guests eat with the occupants of the room. If among the guests are men, then they are seated next to the end of the house. While the male house expert who accompanied him was at the base of the house.

- Edge "lanjar": That which is located on the front of the front wall, is an honorable hall that is commonly used as a place for male guests when a banquet is held.
Under the Rumah Gadang as a place to store agricultural equipment and a place for women to weave. All columns are closed with sparse rows. The size of the house is adjusted to the size of the land. In changing the building mass, the Minangkabau community is not influenced by the needs of space based on hereditary traditions and natural factors. The Rumah Gadang orientation is a settlement formed with a linear pattern that stretches in the direction of the Qibla (direction of prayer in Islam) with position 15 'from west to north with the system facing each other and opposite. The custom element contained in this process is to create a pattern of shared space in order to protect the community in the village. By ritual, if the orientation is right it will bring blessings to the owner. While technically it aims to avoid heating the room (the position of the room is not directly facing toward the sun).

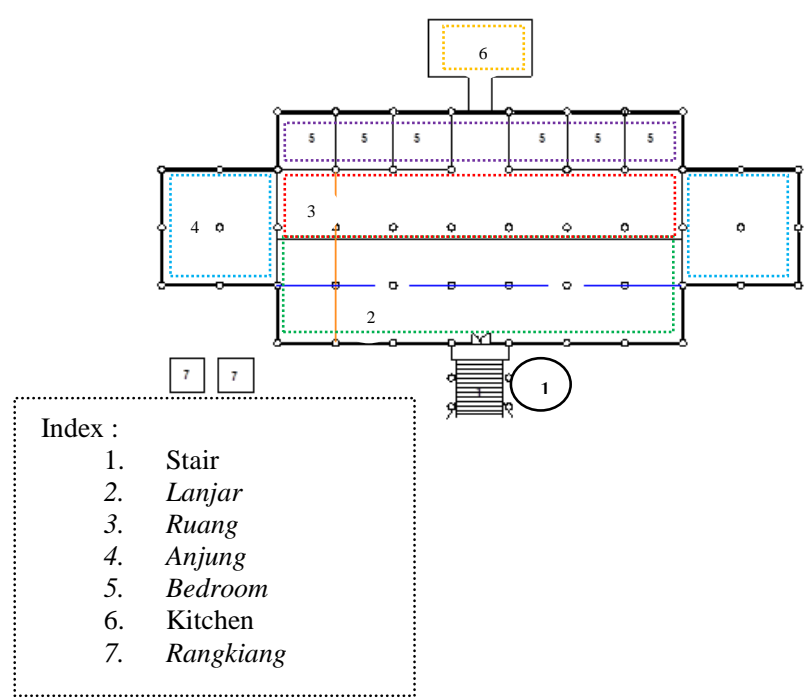

Fig 3. Interior Lay-Out of Pagaruyung Palace (one example of the Rumah Gadang type). Source: (Fatimah,D. 2006)

\section{CONCLUSION}

The interior design of Rumah Gadang shows the existence of the unity between the customs and the religion. The findings conclude that the inclusion of religious rules in adat order, proves the social formation in the culture of the Minangkabau society

\section{ACKNOWLEDGMENT}

Thanks are given to the Pagaruyung and ninik mamak Batu Tagak parties who have provided information and data related to this research.

\section{REFERENCES}

[1] Department of Architecture Report on Field Work Lectures in SUMBAR 'Minangkabau Architecture ", ITB Department of Architecture, Bandung, 1979.

[2] Departemen Pendidikan dan Kebudayaan. Arsitektur Tradisional Daerah Sumatera Barat. 1991 
[3] Hasan, H, Variety of Minangkabau Traditional Houses, Jakarta: Yayasan Citra Pendidikan Indonesia.,2004.

[4] Soeroto, M. Minangkabau. Myrtle Publishing: Jakarta. 2005

[5] Agus,E. Kajian Topologi, Morfologi Dan Tipologi Pada Rumah Gadang Minangkabau. Bung Hatta University. 2011

[6] Couto, N, The Meanings and Visual Elements of the Rumah Gadang Building. (Postgraduate thesis not published), Department of Fine Art., Faculty of Fine Arts and Design ITB, Bandung, 1998.

[7] Yovita,W. Budaya Matrilineal Masyarakat Minangkabau pada Arsitektur Rumah Gadang. ITB, Bandung. 2016
[8] Chalid, I, Matrilineal, the Continuity of the Minangkabau Social System. Retrieved 25 September 2005 from http://www.cimbuak.com. , 2005.

[9] Fatimah,D. Ornamental Variety In Symbol Context In Minangkabau Traditional Architecture. Undergraduated thesis. Deparment of Interior Design. Faculty of Art and Design ITB. Bandung, 2006.

[10] Rapoport, A. House Form and Culture, Prentice-Hall Foundations of Cultural Geography Series: Foundations of Cultural Geography Serie,. California: Prentice-Hell, 1969. 